\title{
Strategic Planning and Reality of External Environment of Organizations in Contemporary Business Environments
}

\author{
Muhammad Wasim Jan Khan \\ PhD Scholar, Faculty of Economics and Business \\ University Malaysia Sarawak, Malaysia \\ E-mail:wasimjanpk@yahoo.com
}

Dr. Muhammad Khalique

Senior Lecturer

Faculty of Economics and Business

University Malaysia Sarawak

E-mail:drmkhalique@gmail.com

Received: October 25, 2014 Accepted: October 29, $2014 \quad$ Published: December 16, 2014

doi:10.5296/bms.v5i2.6794 URL: http://dx.doi.org/10.5296/bms.v5i2.6794

\begin{abstract}
Strategic planning plays an important and key role in the success and survival of all kinds of business organizations. More specifically in the small and medium enterprises which are considered as the back bone of any economy in the present world. Though in current complex world the strategic planning is essential for any organization success in business arenas but the research from the perspective of constituent components of strategic planning is just at the starting point today. Similarly the research from strategic planning perspective in developing countries is very limited. Thus the literature of strategic planning at present is demanding more empirical studies to be conducted and more specifically in the context of small and medium enterprises of developing countries.
\end{abstract}




\section{Macrothink}

Business Management and Strategy ISSN 2157-6068 2014, Vol. 5, No. 2

Keywords: Strategic planning, External environment, Constituent components of strategic planning, Empirical research, Developing countries, Small and medium enterprises, Pakistan 


\section{Introduction of Strategic Planning and its Importance}

Strategic planning and assessment of its value, remains an important and relevant research topic for those interested in organizational and management development (French, Kelly, \& Harrison, 2004). Joel Ross and Michael Kami are of the opinion (as cited in David, 2013) that "Without a strategy, an organization is like a ship, without a rudder going around in circles. It's like a tramp; it has no place to go". In management "Ansoff" introduced the concept of "strategic planning" in early 70s (Feurer \& Chaharbaghi, 1997; Mohamed, Ann, \& Yee, 2010).

From Greek word "strategos" the term "strategy" is derived which means "the roles of a general". The term "planning" in management is a process of preparing ways to use resources more economically, effectively and efficiently, so that the purpose of the company is achieved. Regardless of the sector (business, medical, education and construction etc.), change is inevitable in present business environment. Change exists in all form of organizations and occurs not only physically but can also be seen in terms of utilizing resources (e.g. oil, land, water, etc.) and in using technologies etc (Mohamed et al., 2010). Strategic Planning therefore bridges the gap between where we are, and where we want to go (Alaka, Tijani, \& Abass, 2011).

Teilhard De Chardin, the Jesuit philosopher (as cited in Kaufman, Browne, watkins, \& Leigh, 2003 , p. 27) believed that humans are the only creatures that could both observe and influence their own evolution on the planet, the world around us is changing at high speed that create "future shock" and "information anxiety", so the challenge today is to adjust faster. Therefore the researchers as O'Regan, Sims and Gallear (2008) emphasized that small and medium sized firms will have to engage in strategic planning if they are to survive.

Based on the previous literature review Fletcher and Harris (2002) emphasized that from SMEs perspective the constituent components of strategic planning that are of greater value need to be identified in future researches. Whereas O'Gorman and Doran (1999) warned that the blind adoption of strategic planning models used by large organizations are probably inappropriate for most of the small firms. The only study conducted by French et al. (2004) with such constituent components of strategic planning as (vision, mission, latent abilities of entrepreneurs, market orientation and competitors' orientation) in Australian small firms.

\section{Constituent Components of Strategic Planning}

French et al. (2004) conducted a study in Australia in small firms on the relation between strategic planning and firms' performances with the constituent components of strategic planning as follow (1) vision (2) mission (3) latent abilities of entrepreneurs (4) market orientation and (5) competitors' orientation. But in their conclusion and discussion of their findings French et al. (2004) argued that they have forgot an important component of strategic planning known as customers' orientation in their study and in future studies this important component should be included otherwise the validity of the study will be questionable. Therefore, the study of Khan and Khalique (2014) aims to be conducted with 
the following six/6 substituent components of strategic planning as (1) vision (2) mission (3) latent abilities of entrepreneurs (4) market orientation (5) competitors' orientation and (6) customers' orientation.

\subsection{Vision Statement}

The first step of strategic planning is considered as the development of a "vision statement". It is a statement of an organization "what it wants to become". It guides and shapes an organization and gives purpose and direction to the organization. Vision serves as a motivator for the people inside and outside the organization. The vision statement refers to the future of an organization (Mohamed et al., 2010). A vision is the foundation of the firm's mission statement and is a picture of what a firm wants to be (Hitt, Ireland, \& Hoskisson, 2011).

Organizations having clear vision mean that they know the purpose and direction of their organizations and they can compete in different situations and will prepare themselves well to show better performances then their competitors. For all kinds of businesses the clear vision is important irrespective of the situation that whether the vision is written or unwritten, but the owners and managers should be well known to their vision of organizations. The successful management of business development is based upon strategic awareness capability; how one identifies and conceptualizes one's world, recognizes events in the world, interprets these events, and makes decisions leading to appropriate actions (Atherton \& Hannon, 1996a). A review of past studies examining the impact of market orientation on financial performance of firms' reveals that being a culturally embedded philosophy, market orientation facilities the clarity of vision and focus for the efforts of the individuals and departments within the organization, thereby enabling the organization to evolve and pursue "consistent" and "workable" strategies (Kohli \& Jaworshi, 1990).

The visionary under-achiever has difficulty in translating the opportunities generated by high strategic awareness capacity into business development activity and because of poor planning effectiveness (Hannon \& Atherton, 1997). Strategic planning includes developing vision and mission statements, performing internal (looking at the strengths and weaknesses) and external (looking at the opportunities and threats) audit establishing long term objectives and then generate and select better strategies (David, 2013).

Strategic planning for all kind of industries has become absolutely crucial in today's scenario. As never before there have they been confronted with such substantial increases in both uncertainty and competition without any doubt for the organizations. Strategic planning is useful not only because it can realize the vision of the upper management or it can mitigate unforeseen risks; it also has many more benefits (Vel, Creed, \& Narayan, 2012). Similarly French et al. (2004) found no relationship between vision of small firms and performances' of small firms. Reave (2005) stated that measuring of vision alone in organizations and at the moment when the leader is having a clear understanding of where the group is going and also have a clear sense of where he/she wants the organization to be in five years, has been found to have a negative association with continuance commitment and follower confidence. 


\subsection{Mission Statement}

Mission is a statement of an organization which deals with questions like "what is our business?", "why are we here?" and "why do we exist?" The mission statement refers to present and is a way of behaving and is concerned with the way an organization is managed today with its purpose. The mission statement of an organization should be clear and concise in order to distinguish it from others (Mohamed et al., 2010).

Mission statement realize the questions like "what is our business?", "why are we here?" and "why do we exist?" Irrespective of the situation that whether the mission of organization is written or unwritten, the owners and employees must be clear and well known to the mission of organization as it is the mission of firms which leads them towards their vision.

O'Gorman and Doran (1999) reported that the presence of a mission statement or formal mission does not seem to have any direct effect on the success of small enterprises. Similarly French et al. (2004) also found no relationship between mission and small firms' performance. Whereas the Karabulut and Efendioglu (2010) conducted a study in Turkish firms and reported that a "mission statement" identifies and define the importance of the process of strategic planning in the organization and has significant impacts on the profitability of the firms. They found mission statement that was correlated (positively influenced) and statistically significant with profitability of the Turkish firms.

\subsection{Latent Abilities of the Entrepreneurs}

The ability of entrepreneurs to assimilate new external knowledge and the skill to successfully use such knowledge for commercial purposes contributes to the exploitation of opportunities (Tsai, 2001). All firms have physical, intellectual and cultural resources which in turn combine to give the firm its capabilities such as designing, manufacturing, marketing etc. Capabilities which deliver a firm competitive advantage over competitors are called its competencies (Munir, Lim, \& Knight, 2011).

Many experts expect strategy, intelligence, even ruthlessness to be marks of a successful leader (Reave, 2005). A review of extant literature and the studies of Carter, Gartner and Reynolds (1996), Gibb and Scott (1985), Harris and Ogbonna (2006) and Hunt and Handler (1999) lead to the suggestion that there are four key characteristics of management which are related to the initiation of planning. The first important factor centers on the extent to which management possesses relevant and applicable planning skills. That is, the extent to which the management of the firm have the skills to be able to undertake or to manage a formal planning effort.

Rafferty and Griffin (2004) reported that "in the absence of encouragement and confidence building efforts, articulating a vision may have a neutral or even negative influence on employees". Finally, many leaders or organizations present lofty vision statements that are rarely referenced in the course of daily practice or worse and they are actually contradicted in daily practice. Assessing observable personal qualities and behaviors may provide more 
accurate information for theory building (Reave, 2005). The study of French et al. (2004) conducted in small Australian firms found no relationship between latent abilities of owners/managers and small firms' performances.

\subsection{External Environment Analysis}

In today's world, the company ability to adopt the changes will determine its success and sustainability or even survival. As today the global environment has been changing dramatically and the firms face many new challenges daily. There are lots of competitive pressures and risks which prevent the businesses to achieve their goals (Akdogan \& Cingoz, 2012). Environmental scanning as one of the important components of strategic planning process has received importance to explore new opportunities and to identify threats for making important strategic decision. Authors in the area of entrepreneurship and small businesses have recognized the need for continuous and conscious study of the environment and integrate the environmental information into their strategic planning (Balasundaram, 2008).

Strategic planning deals the logic which guides the process by which an organization adapts to its external environmental (Ansoff, 1987). The businesses leaders (owners) need awareness and understanding of the external operating environment of their firms in order to align their firm's strategies with external environment conditions (Bettis \& Hitt, 1995; Wholey \& Brittain, 1989). A firm's propensity to directly and intensely challenge its competitors to achieve entry and remain sustainable in the market place refers to competitive aggressiveness of the firm. It is only possible through the thorough examination of external environment of the business (Lumpkin \& Dess, 1996).

It is critical to both business management and planning process to understand the environment in which small business operates (Hannon \& Atherton, 1997). By the external environment focus business firms can adapt market change and these enterprises have been recognized as prospector adaptive businesses (Wright, Kroll, Pray, \& Lado, 1995). Feurer and Chaharbaghi (1995) and Feurer and Chaharbaghi (1997) narrated that by demonstrating the need to match business opportunities with the strategic planning, Ansoff laid the foundation for the usefulness of strategic planning. In 1980s the strategic planning focus shifted and started to broad range of concepts and techniques aiming at the anticipating and exploiting business opportunities. In small businesses strategic planning must be made with sufficient understanding of the external environments as every business have dynamic external environment (Spillan \& Ziemnowicz, 2003). The external environment analysis helps in increasing efficiency and effectiveness of planning in smaller enterprises (Kraus, Harms, \& Schwarz, 2006).

Hodgetts and Kuratko (2001) mentioned that by generating relevant information and understanding important environment, strategic planning can contribute to performance. The changing external environment conditions impacts on all companies' strategic direction and overall performance (O'Regan et al., 2008). Generally opportunities for businesses are hidden 
in the external environments of the businesses (David, 2013; Hitt, Ireland, Sirmon, \& Trahms, 2011). The companies need to prepare plans to cope with changes as they face dynamically changing environments especially such changes may be unpredictable and may occur suddenly (Phelps, Chan, \& Kapsalis, 2001).

Domestic firms competing within emerging economies face a "high velocity" environment of rapid political, institutional and economic changes that are accompanied by product markets and relatively underdeveloped factors (Wright, Filatotchev, Hoskisson, \& Peng, 2005). In dynamic environments where demand constantly shifts, opportunities become abundant and performance should be highest for those firms that have an orientation for pursuing new opportunities because they have a good fit between their strategic orientation and the environment (Wiklund \& Shepherd, 2005).

The ability of corporations to manage their environmental performance is emerging as a strategic issue for many companies worldwide and is primarily because the environment is now regarded as an asset to be valued (Ann, Zailani, \& Wahid, 2006). The external environment of firms' affects their ability and the ability of individuals to create or discover opportunities. Environmental munificence facilitates the ability to exploit the resources, acquiring resources, as well as identifying opportunities to create competitive advantage (Hitt et al., 2011). White (2000) reported that the external environment and internal capacities have significant effects on technology decisions among Chinese state-owned enterprises. Nowadays organizations are facing big challenges to make their knowledge more productive as a competitive resource in a complex and an unpredictable environment (Daud \& Yusoff, 2011).

\subsection{Market Orientation}

In the market orientation literature, the relationship between market orientation and performance is considered as cornerstone (Haugland, Myrtveit, \& Nygaard, 2007). Dess and Beard (1984) stressed that managers should first select specific market for attention and then they tend to identify a specific customers focus. Whereas to Drucker (1999, p. ix) "we live in a period of profound transition". Narver and Slater (1990) argued that a business to improve its market performance will have to increase its market orientation.

Market orientation is considered as the heart of strategy and modern marketing management. Market Orientation is part of culture building, when an organization aims to be a market oriented organization it needs to develop a systematic adjustment system, systematically collect information, a working self-assessment, and analyze competitors and customers in the market and lastly disseminate the knowledge to the entire organization (Kohli \& Jaworski, 1990).

The term market orientation is also known as market driven, customer focused and customer centric (Deshpande, 1999). Better quality of marketing planning assists managers seeking to implement a market orientation to achieve their goal, or conversely market orientation assists planning by providing a clear and unambiguous goal that serves to focus the planning effort 
(Pulendran, Speed, \& Widing, 2003). Every manager in a business must think broadly about firm's market orientation and the scope of its strategic maneuvers. The survival and success of a small business is often determined by these decision areas (Spillan \& Ziemnowicz, 2003). The advantages of market orientation to the businesses have been evidently documented in the western economies. However there has been done little research into these practices and their impact on firm performance in emerging economies (Liu, Luo, \& Shi 2003).

The market orientation provides a firm a better understanding of its competitors, customers and environment, which subsequently leads to superior firm performance (Kara, Spillan, \& Deshields, 2005). The business culture that produces outstanding performance through its commitment to creating superior value for customers refers to market orientation. The beliefs implicit in this culture are embedded in continuous cross-functional learning about customers latent and expressed needs and about competitors' capabilities and strategies and also in cross-functionally coordinated action to create and exploit the learning. It was concluded that business performance is affected by market orientation (Narver \& Slater, 1990; Slater \& Narver, 2000). Mohsin, Halim and Ahmad (2012) reported that market orientation allows owner-managers to gather information from the current and potential customers needs to create superior customer values and respond in an entrepreneurial manner.

Hult, Tomas and Ketchen (2001) stated that research shows that a strong market orientation enhances a company's market sensing capabilities, which in turn encourages the development of products, processes and new ideas and enhances the likelihood of new product success (Subin \& Workman, 2004). Over all research on the field of market orientation, competitors' orientation and customer orientation field has been traditionally oriented to the study of major corporations. Cohen and Kaimenakis (2007) reported that there are only a few studies that have been carried out on small and medium-sized enterprises in order to assess the existence of market orientation relationship to business performance. Spanjol, Qualls and Rosa (2009) mentioned that competitor and customer orientations are sometimes encompassed in the composite construct of market orientation.

Narver and Slater (1990) concluded a positive relationship between market orientation and business profitability in a sample of product and service businesses operating in a variety of industries. The findings of a study conducted by Jaworshi and Kohli (1993) suggested that market orientation responsible to over all judgmental performance of business. Chang and Chen (1998) reported that overall more market-oriented business units seem to enjoy a higher level of business performance. Han, Kim and Srivastava (1998) reported in their study that market orientation facilitating an organization's capacity to innovate which in turn positively influences its business performance. Slater and Narver (2000) reported that the market orientation and business performance (profitability) are positively related.

Pulendran, Speed and Widing (2003) found a positive and significant relationship between market orientation and business performance in a study conducted by. Kara et al. (2005) indicated a significant link between market orientation and small-sized service retailer performance. Kropp, Lindsay and Shoham (2006) found a positive relationship between 
market orientation and firms' performance in their study conducted in Republic of South Africa. Baker and Sinkula (2007) reported that market orientation is positively and significantly associated with new product success, and enhances organizational performance through increasing a firm's innovativeness. Haugland, Myrtveit and Nygaard (2007) reported in their study conducted in hotel industry, that market orientation has only a modest effect on relative productivity and no effect on return on assets. The Study of French et al. (2004) found no relationship between market orientation and small firms' performances.

\subsection{Competitors' Orientation}

Hannan and Freeman $(1984 ; 1989)$ emphasized and also supported by Harris and Ogbonna (2006) that a key driver of organizational inertia is a lack of information about the key competitors of the business and in-depth insight of the scenario regarding competition. Hand, Sineath and Howle (1987) also stressed that particular attention should be paid to competitor's actions in small businesses. The extent to which firms are oriented toward and understand not only the strengths and weaknesses but also the tactical and strategic capabilities of both current and potential competitors is called as competitor orientation of a firm. The lack of knowledge of a firm about its competitors drags it into troubles (Harris \& Ogbonna, 2006).

Temtime (2003) also stressed that nowadays for success and survival the use of strategic planning is necessary because of the increasing intensity of competition in the market. As for small businesses the ever changing competitive business environment often requires to adapt quickly to a challenging environment. SMEs face competition from bigger corporations as well. Thus in order to be more competitive, resilient and relevant in the business world, SMEs need to prioritize, identify, and minimize their business challenges in today's world (Talib, Ali, \& Idris, 2013).

Brokner (1992) and McCarthy, Schoorman and Cooper (1993) mentioned that the organizations and their management who are ignorant of competitor actions are less likely to instigate efforts to change. In such conditions, firms with existing strategies are likely to become increasingly committed to their current course of action with no planning process and the initiation of planning is unlikely. Competitors' orientation encompasses the extent to which firms are oriented toward and understand not only the strengths and weaknesses but also the strategic capabilities and tactical of both current and potential competitors. The need for and benefits of planning become prioritized and uctioned as long as firms' become oriented toward the activities of competitors (Harris \& Ogbonna, 2006). In the context of SMEs, Pelham and Wilson (1996) have shown a positive association between market (customer and competitive) orientation and performance. The customer and market focus, planning and external environment are found among those factors which influence SMEs business success in Thailand (Islam, Keawchana, Yusuf, \& Chittithaworn, 2011). Similarly French et al. (2004) conducted a study in Australian small firms and found no relationship between competitors' orientation and the small firms' performances. 


\subsection{Customers' Orientation}

Kim, Park and Yoon (1997) argued that to survive in today's competitive market environment, companies must be capable to meet customers' requirements with emphasis on production of products of high quality, in time delivery and low cost. The entrepreneurs should also focus on customer needs, focusing on the customers and their needs seems a certain way to succeed and to avoid the worst kind of surprises specially in turbulent environments such as the new competitive landscape, where competitors can come from any line of business or any nation without warning (Meyer \& Heppard, 2001). When an organization is competitor and customer oriented, it emphasizes on the search of information and use geared toward meeting customer needs and achieving competitive advantage (Han et al., 1998).

For concern of success of small businesses, one of the keys to successful marketing is the willingness to focus on service-orientation when selling products and services. Since customers have become more selective and conservative in their buying habits, and larger companies are more forceful in attaining target markets. In order to retain customers' loyalty and substantial competitive edge in the market; small businesses must focus on meeting customer needs (Carraher, Parnell, \& Spillan, 2009).

Alas and Vadi (2006), Becherer and Maurer (1999), Froehle and Roth (2004), Hipkin (2000) and O'Gorman and Doran (1999) also reported that by managing the types of behaviors and employees display, firms often attempt to shape their image with customers. The customers' service employees play a vital boundary-spanning role for the organizations as an organization's success depends on effective customer relations (Robertson, 1995). The care for customers and good relations with customers are important in small and medium sized enterprises where nearly all employees have contact with both external and internal customers on a daily basis (O’Gorman \& Doran, 1999; Parnell, Carraher, \& Odom, 2000).

In the context of SMEs the study Pelham and Wilson (1996) showed a positive association between market (customer and competitive) orientation and performance. In a study conducted by Wright, Pearce and Busbin (1997) found that firms which emphasize customer service report higher rate of profitability, return on assets, return on investments, return on sales, and profit growth than those reporting a lower emphasis on customer service by the individual employees. Appiah-Adu and Singh (1998) presented a positive relationship between customer orientation and SMEs performance. Han et al. (1998) reported in their study that market orientation facilitating an organization's capacity to innovate, which in turn positively influences its business performance. At the component level of analysis they found that customer orientation component was the dominant factor responsible for this phenomenon. Whereas Verhees and Meulenberg (2004) suggested that customer market intelligence positively affects performance.

\section{Conclusion}

As it has been discussed in detail and well understood that in the world today, which is very challenging and uncertain and the strategic planning practice is the most reliable and effective 
way to compete with these challenges for every kind of businesses. But still there is need of empirical research to be done from strategic planning perspective and to explore the constituent components of strategic planning in empirical research in developing countries. Till today, there is found no empirical study from strategic planning perspective in the context of Pakistan and more specifically from constituent components of strategic planning perspective. Therefore, the researcher aims to conduct the first empirical study in the context of Pakistan from the perspective of constituent components of strategic planning.

\section{References}

Akdogan, A. A., \& Cingoz, A. (2012). An empirical study on determining the attitudes of small and medium sized businesses (SMEs) related to coopetition. Social and Behavioral Sciences, $8^{\text {th }}$ International Strategic Management Conference, 58, 252-258.

Alaka, N. S., Tijani, A. A., \& Abass, O. A. (2011). Impact of strategic planning on the performance of insurance companies in Nigeria. European Journal of Humanities and Social Sciences, 5(1), 136-152.

Alas, R., \& Vadi, M. (2006). The employees attitudes and their connections with the organisational culture in the process of change in the Estonian organizations. Baltic Journal of Management, 1(1), 49-66. http://dx.doi.org/10.1108/17465260610640877

Ann, G. E., Zailani, S., \& Wahid, N. A. (2006). A study on the impact of environmental management system (EMS) certification towards firms' performance in Malaysia. Management of Environmental Quality: An International Journal, 17(1), 73-93. http://dx.doi.org/10.1108/14777830610639459

Ansoff, H. I. (1987). The emerging paradigm of strategic behavior. Strategic Management Journal, 8(6), 501-515. http://dx.doi.org/10.1002/smj.4250080602

Appiah-Adu, K., \& Singh, S. (1998). Customer orientation and performance: a study of SMEs. Management Becision, 365-394. http://dx.doi.org/10.1108/00251749810223592

Atherton, A., \& Hannon, P. D. (1996a). Thinking About Strategic Awareness Capability. Durham University Business School, Durham, UK.

Baker, W. E., \& Sinkula, J. M. (2007). Does market orientation facilitate balanced innovation programs? An organizational learning perspective. Journal of Product Innovation Management, 24(4), 316-334. http://dx.doi.org/10.1111/j.1540-5885.2007.00254.x

Balasundaram, N. (2008). A relationship between owner-manager's environmental awareness and small business performance. University of Jaffna, Jaffna, Sri Lanka. Working papers series. Available at: http://papers.ssrn.com/sol3/papers.cfm?abstract_id=1728645

Becherer, R., \& Maurer, J. (1999). The proactive personality disposition and entrepreneurial behavior among small company presidents. Journal of Small Business Management, 37(1), 
28-36.

Bettis, R. A., \& Hitt, M. A. (1995). The new competitive landscape. Strategic Management Journal, Special Issue: Technological transformation and the new competitive landscape, 16, 7-19. http://dx.doi.org/10.1002/smj.4250160915

Brockner, J. (1992). The escalation of commitment to a failing course of action: towards theoretical progress. Academy of Management Review, 17(1), 39-61.

Carraher, S., Parnell, J. A., \& Spillan, J. E. (2009). Customer service-orientation of small retail business owners in Austria, The Czech Republic, Hungary, Latvia, Slovakia, and Slovenia. Baltic Journal of Management, 4(3), 251-268. http://dx.doi.org/10.1108/17465260910990975

Carter, N. M., Gartner, W. B., \& Reynolds, P. D. (1996). Exploring start-up event sequences. Journal of Business Venturing, 11(2), 89-105.

Chang, T. Z., \& Chen, S. J. (1998). Market orientation, service quality and business profitability: a conceptual model and empirical evidence. The Journal of Services Marketing, 12(4), 246-264. http://dx.doi.org/10.1108/08876049810226937

Cohen, S., \& Kaimenakis, N. (2007). Intellectual capital and corporate performance in knowledge-intensive SMEs. The Learning Organization, 14(3), 241-262. http://dx.doi.org/10.1108/09696470710739417

Daud, S., \& Yusoff, W. F. W. (2011). How intellectual capital mediates the relationship between knowledge management processes and organizational performances. African Journal of Business Management, 5(7), 2607-2617.

David, F. R. (2013). Strategic management, A Competitive Advantage Approach (Concepts \& Cases). (14 $4^{\text {th }}$ Ed.). New Jersey, United States of America: Prentice Hall, Pearson Education.

Deshpande, R. (1999). Developing a Market Orientation. Thousand Oaks, CA: Sage Publications.

Drucker, P. (1999). Management Challenges for the 21st Century. Harper Business, New York, NY.

Feurer, R., \& Chaharbaghi, K. (1995). Strategy development: past, present and future. The dynamic environments of today require a more dynamic approach to strategy development. Management Decision, 33(6), 11-21. http://dx.doi.org/10.1108/00251749510087614

Feurer, R., \& Chaharbaghi, K. (1997). Strategy development: past, present and future. Training for Quality, MCB University, 5(2), 58-70. http://dx.doi.org/10.1108/09684879710167647

Fletcher, M., \& Harris, S. (2002). Seven aspects of strategy formation: exploring the value of planning. International Small Business Journal, 20(3), 297-314. 
http://dx.doi.org/10.1177/0266242602203004

French, S. J., Kelly, S. J., \& Harrison, J. L. (2004). The role strategic planning in the performance of small, professional service firms (A research note). Journal of Management Development, 23(8), 765-776. http://dx.doi.org/10.1108/02621710410549611

Froehle, C., \& Roth, A. V. (2004). New measurement scales for evaluating perceptions of the technology-mediated customer service experience. Journal of Operations Management, 1-21. http://dx.doi.org/10.1016/j.jom.2003.12.004

Gibb, A., \& Scott, M. (1985). Strategic awareness, personal commitment and the process of planning in the small business. Journal of Management Studies, 22(6), 598-631. http://dx.doi.org/10.1111/j.1467-6486.1985.tb00014.x

Han, J. K., Kim, N., \& Srivastava, R. K. (1998). Market orientation and organizational performance: is Innovation a missing link? Journal of Marketing, 62, 30-45. http://dx.doi.org/10.2307/1252285

Hand, H. W., Sineath, P., \& Howle, W. E. (1987). Small business concepts and their relationship to performance: a field study of retail service stations. Journal of Small Business Management, 25(2), 55-63.

Hannan, M., \& Freeman, J. (1984). Structural interim and organizational change. American Sociological Review, 49(2), 149-164. http://dx.doi.org/10.2307/2095567

Hannan, M., \& Freeman, J. (1989). Population Ecology. Boston, MA. Harvard University Press.

Hannon, P. D., \& Atherton, A. (1997). Small firm success and the art of orienteering: the value of plans, planning, and strategic awareness in the competitive small firm. Journal of Small Business and Enterprise Development, 5(2), 102-119. http://dx.doi.org/10.1108/EUM0000000006759

Harris, L. C., \& Ogbonna, E. (2006). Initiating strategic planning. Journal of Business Research, 59, 100-111. http://dx.doi.org/10.1016/j.jbusres.2005.02.003

Haugland, S. A., Myrtveit, I., \& Nygaard, A. (2007). Market orientation and performance in the service industry: a data envelopment analysis. Journal of Business Research, 60, 1191-1197. http://dx.doi.org/10.1016/j.jbusres.2007.03.005

Heriot, K. C., Campbell, N. D., \& Finney, R. Z. (2004). Omitted variable bias in the link between planning and performance. New England Journal of Entrepreneurship, 7(2), 27-31.

Hipkin, I. (2000). TQM: the paradox of empowerment and conformance in the service sector. South African Journal of Business Management, 31(1), 1-8.

Hitt, M. A., Ireland, R. D., \& Hoskisson, R. E. (2011). Strategic Management, Competitiveness and Globalization: Concepts and Cases (9th Ed.). South-Western Cengage 
Learning. Mason- United States of America. ISBN 13: 978-1-4390-4230-4., ISBN 10: $1-4390-4230-6$.

Hitt, M. A., Ireland, R. D., Sirmon, D. G., \& Trahms, C. A. (2011). Strategic entrepreneurship: creating value for individuals, organizations, and society. Mays Business School Research Paper No. 2012-19.

Hodgetts, R. M., \& Kuratko, D. F. (2001). Effective Small Business Management. Dryden, Fort Worth, TX.

Hult, G., Tomas, M., \& Ketchen, D. J. Jr. (2001). Does market orientation matter? A test of the relationship between positional advantage and performance. Strategic Management Journal, 22(9), 899-906. http://dx.doi.org/10.1002/smj.197

Hunt, J. M., \& Handler, W. C. (1999). The practices of effective family firm leaders. Journal of Developmental Entrepreneurship, 4(2), 135-151.

Islam, M. A., Keawchana, T., Yusuf, D. H. M., \& Chittithaworn, C. (2011). Factors affecting business success of small \& medium enterprises (SMEs) in Thailand. Asian Social Science, 7(5), 180-190.

Jaworski, B. J., \& Kohil, A. K (1993). Market orientation: antecedents and consequences. Journal of Marketing, 57, 53-70. http://dx.doi.org/10.2307/1251854

Kara, A., Spillan, J. E., \& Deshields, O. W. Jr. (2005). The effect of market orientation on business performance: a study of small-sized service retailers using MARKOR scale. Journal of Small Business Management, 43(2), 105-118. http://dx.doi.org/10.1111/j.1540-627x.2005.00128.x

Karabulut, A. T., \& Efendioglu, A. M. (2010). Impact of strategic planning on financial performance of companies in Turkey. International Journal of Business and Management, 5(4), 3-12.

Kaufman, R., Browne, H. O., Watkins, R., \& Leigh, D. (2003). Strategic Palnning for Success (Aligning People, Performance and Payoffs). 989 market street, San Francisco, United States of America: Jossey-Bass/Pfeiffer, A Wiley Imprint. ISBN: 0-7879-6503-03. Page. 85.

Khan, M. W. J., \& Khalique, M. (2014). Entrepreneurial approach and intellectual capital in Pakistani manufacturing pharmaceutical organizations. $6^{\text {th }}$ International Borneo Business Conference, Kuching, Malaysia, (IBBC) 20-21 August, 2014.

Kim, G. Park, C. S., \& Yoon, K. P. (1997). Identifying investment opportunities for advanced manufacturing systems with comparative integrated performance measurement. International Journal Production Economics, 50, 23-33. http://dx.doi.org/10.1016/S0925-5273(97)00014-5

Kohli, A. K., \& Jaworski, B. J. (1990). Market Orientation: the construct, research propositions and managerial implications. Journal of Marketing, 54, 1-18. 
http://dx.doi.org/10.2307/1251866

Kraus, S., Harms, R. \& Schwarz, E. J. (2006). Strategic planning in smaller enterprises-new empirical findings. Management Research News, 29(6), 334-344. http://dx.doi.org/10.1108/01409170610683851

Kropp, F., Lindsay, N. J., \& Shoham, A. (2006). Entrepreneurial, market, and learning orientations and international entrepreneurial business venture performance in South African firms. International Marketing Review, 23(5), 504-523. http://dx.doi.org/10.1108/02651330610703427

Liu, S. S., Luo, X., \& Shi, Y. Z. (2003). Market-oriented organizations in an emerging economy: A study of missing links. Journal of Business Research, 56, 481-491. http://dx.doi.org/10.1016/S0148-2963(01)00265-X

Lumpkin, G. T., \& Dess, G. G. (1996). Clarifying the entrepreneurial orientation construct and linking it to performance. The Academy of Management Review, 21(1), 135-172.

McCarthy, A. M., Schoorman, F. D., \& Cooper, A. C. (1993). Reinvestment decisions by entrepreneurs: Rational decision-making or escalation of commitment. Journal of Business Venturing, 8(1), 9-24. http://dx.doi.org/10.1016/0883-9026(93)90008-S

Meyer, G. D., \& Heppard, K. A. (2001). Entrepreneurship as Strategy: competing on the entrepreneurial edge. The Academy of Management Review, 26(1), 133-135.

Mohamed, Z. A., Ann, H. J., \& Yee, W. F. (2010). Strategic Management. 40150, Shah Alam, Selangor Darul Ehsan, Malaysia: Oxford Fajar Sdn.Bhd. Oxford University Press.

Mohsin, A. M. A., Halim, H. A., \& Ahmad, N. H. (2012). Delving into the issues of entrepreneurial attitude orientation and market orientation among the SMEs, a conceptual paper. International Congress on Interdisciplinary Business and Social Science 2012 (ICIBSOS 2012). Procedia, Social and Behavioral Sciences, 65, 731-736.

Munir, A., Lim, M. K., \& Knight, L. (2011). Sustaining competitive advantage in SMEs. Social and Behavioral Sciences. The 2011 International (European) Conference on Asia Pacific Business Innovation \& Technology Management, 25, 408-412.

Narver, J. C., \& Slater, S. F. (1990). The effect of market orientation on business profitability. Journal of Marketing, 20-35. http://dx.doi.org/10.2307/1251757

O'Gorman, C., \& Doran, R. (1999). Mission statements in small and medium-sized businesses. Journal of Small Business Management, 37(4), 59-68.

O’Regan, N., Sims, M. A., \& Gallear, D. (2008). Leaders, loungers, laggards, the strategic planning environment performance relationship re-visited in manufacturing SMEs. Journal of $\begin{array}{llll}\text { Manufacturing Technology } & \text { Management, } & \text { 6-21. }\end{array}$ http://dx.doi.org/10.1108/17410380810843426 
Parnell, J., Carraher, S., \& Odom, R. (2000). Strategy and performance in the entrepreneurial computer software industry. Journal of Business \& Entrepreneurship, 12(3), 49-66.

Pelham, A., \& Wilson, D. (1996). A longitudinal study of the impact of market structure, firm structure, strategy, and market orientation culture on dimensions of performance. Journal of the Academy of Marketing Science, 24, 27-43. http://dx.doi.org/10.1007/BF02893935

Phelps, R., Chan, C., \& Kapsalis, S. C. (2001). Does scenario planning affect performance? Two exploratory studies. Journal of Business Research, 51, 223-232. http://dx.doi.org/10.1016/S0148-2963(99)00048-X

Pulendran, S., Speed, R., \& Widing, R. E. (2003). Marketing planning, market orientation and business performance. European Journal of Marketing, 37(3/4), 476-497. http://dx.doi.org/10.1108/03090560310459050

Rafferty, A. E., \& Griffin, M. A. (2004). Dimensions of transformational leadership: conceptual and empirical extensions. The Leadership Quarterly, 15(3), 329-354. http://dx.doi.org/10.1016/j.leaqua.2004.02.009

Reave, L. (2005). Spiritual values and practices related to leadership effectiveness. The Leadership Quarterly, 16, 655-687. http://dx.doi.org/10.1016/j.leaqua.2005.07.003

Robertson, P. J. (1995). Involvement in boundary spanning activity: mitigating the relationship between work setting and behavior. Journal of Public Administration Research and Theory, 5(1), 73-98.

Slater, S. F., \& Narver, J. C. (2000). The positive effect of a market orientation on business profitability: a balanced replication. Journal of Business Research, 48, 69-73. http://dx.doi.org/10.1016/S0148-2963(98)00077-0

Spanjol, J., Qualls, W. J., \& Rosa, J. A. (2009). How many and what kind? The role of strategic orientation in new product ideation. Journal of Product Innovation Management, 28(2), 236-250. http://dx.doi.org/10.1111/j.1540-5885.2010.00794.x

Spillan, J. E., \& Ziemnowicz, C. (2003). Strategic management in small retail businesses: the case of Guatemala. International Small Business Journal, 21(4), 461-478. http://dx.doi.org/10.1177/02662426030214005

Subin, I. M., \& Workman, J. P. Jr. (2004). Market orientation, creativity, and new product performance in high-technology firms. Journal of Marketing, 68, 114-132. http://dx.doi.org/10.1509/jmkg.68.2.114.27788

Suklev, B., \& Debarliev, S. (2012). Strategic planning effectiveness comparative analysis of the Macedonian context. Economic and Business Review, 14(1), 63-93.

Talib, H. H. A., Ali, K. A. M., \& Idris, F. (2013). Quality management framework for the SME's food processing industry in Malaysia. International Food Research Journal, 20(1), 147-164. 
Temtime, Z. T. (2003). The moderating impacts of business planning and firm size on total quality management practices. The TQM Magazine, 15(1), 52-60. http://dx.doi.org/10.1108/09544780310454457

Tsai, W. (2001). Knowledge transfer in intra-organizational networks: Effects of network position and absorptive capacity on business unit innovation and performance. Academy of Management Journal, 44, 996-1004. http://dx.doi.org/10.2307/3069443

Vel, P., Creed, B., \& Narayan, R. S. (2012). The corporate strategy of Dubai Duty Free. Asian Journal of Business and Management Sciences, 2(6), 40-52.

Verhees, F. J. H. M., \& Meulenberg, M. T. G. (2004). Market orientation, innovativeness, product innovation, and performance in small firms. Journal of Small Business Management, 42(2), 134-154. http://dx.doi.org/10.1111/j.1540-627X.2004.00102.x

White, S. (2000). Competition, capabilities, and the make, buy, or ally decisions of Chinese state-owned firms. The Academy of Management Journal, 43(3), 324-341. http://dx.doi.org/10.2307/1556398

Wholey, D. R., \& Brittain, J. (1989). Characterizing environmental variation. The Academy of Management Journal, 32(4), 867-882. http://dx.doi.org/10.2307/256572

Wiklund, J., \& Shepherd, D. (2005). Entrepreneurial orientation and small business performance: a configurational approach. Journal of Business Venturing, 20, 71-91. http://dx.doi.org/10.1016/j.jbusvent.2004.01.001

Wright, M., Filatotchev, I., Hoskisson, R. E., \& Peng, M. W. (2005). Guest editors' introduction; strategy research in emerging economies: challenging the conventional wisdom. Journal of Management Studies, 42(1), 1-33. http://dx.doi.org/10.1111/j.1467-6486.2005.00487.x

Wright, N., Pearce, J., \& Busbin, J. (1997). Linking customer service-orientation to competitive performance: does the marketing concept really work? Journal of Marketing Theory and Practice, 5(4), 23-33.

Wright, P., Kroll, M., Pray, B., \& Lado, A. (1995). Strategic orientation, competitive advantage, and business performance. Journal of Business Research, 33, 143-151. http://dx.doi.org/10.1016/0148-2963(94)00064-L

\section{Authors}

Muhammad Wasim Jan Khan is currently a PhD Scholar (Strategic Management) in Faculty of Economics and Business, University Malaysia Sarawak, Malaysia. He is the first researcher going to observe the concept of strategic planning in small and medium enterprises (SMEs) in the context of Pakistan; specifically in pharmaceutical SMEs. He is also the first author going to explore the concept of strategic planning with the intellectual capital in empirical research in SMEs; specifically in SMEs of Pakistan. His research interest includes 
strategic planning, intellectual capital, entrepreneurship, SMEs and organizational performance.

Dr. Muhammad Khalique is a Senior Lecturer in Faculty of Economics and Business, University Malaysia Sarawak, Malaysia.

\section{Copyright Disclaimer}

Copyright for this article is retained by the author(s), with first publication rights granted to the journal.

This is an open-access article distributed under the terms and conditions of the Creative Commons Attribution license (http://creativecommons.org/licenses/by/3.0/). 